\title{
Effect of Irrigations and Fertilizers Management on Growth and Yield of Wheat (Triticum aestivum L.) under Different Date of Sowing
}

\author{
Princy Jain*, K. K. Agrawal and Manish Bhan
}

Dept. of Agronomy, Jawaharlal Nehru Krishi Vishwa Vidyalaya, Jabalpur, Madhya Pradesh (482 004), India

\section{Corresponding Author}

Princy Jain

e-mail: princyjnkvv@gmail.com

\author{
Article History \\ Article ID: AR1908 \\ Received in $27^{\text {th }}$ September, 2018 \\ Received in revised form $08^{\text {th }}$ October, 2018 \\ Accepted in final form $11^{\text {th }}$ October, 2018
}

\begin{abstract}
A field experiment was conducted at Jawaharlal Nehru Krishi Vishwa Vidyalaya, Jabalpur, Madhya Pradesh, India during the winter season of 2015-16, to study the effect of different irrigation and fertilizer levels on wheat variety MP 3288. The experiment comprises of under three sowing dates $\left(2^{\text {nd }}\right.$ December, $22^{\text {nd }}$ December and $12^{\text {th }}$ January), irrigations schedules (Three irrigations at CRI+flowering stage+milk stage and Four irrigations at CRI+late jointing stage+flowering stage+milk stage) and four fertility levels (No fertilizer, $60 \mathrm{~N} \mathrm{~kg} \mathrm{ha}^{-1}: 30 \mathrm{P}_{2} \mathrm{O}_{5}$ $\mathrm{kg} \mathrm{ha}^{-1}: 20 \mathrm{k}_{2} \mathrm{O} \mathrm{kg} \mathrm{ha}{ }^{-1}, 120 \mathrm{~N} \mathrm{~kg} \mathrm{ha}^{-1}: 60 \mathrm{P}_{2} \mathrm{O}_{5} \mathrm{~kg} \mathrm{ha}^{-1}: 40 \mathrm{k}_{2} \mathrm{O} \mathrm{kg} \mathrm{ha}{ }^{-1}$ and $\left.180 \mathrm{~N} \mathrm{~kg} \mathrm{ha}^{-1}: 90 \mathrm{P}_{2} \mathrm{O}_{5} \mathrm{~kg} \mathrm{ha}^{-1}: 60 \mathrm{k}_{2} \mathrm{O} \mathrm{kg} \mathrm{ha}{ }^{-1}\right)$. Sowing time with proper application of irrigation and fertilizer significantly influenced yield attributes and ultimately yield of the wheat. Superior grain yield (2.98, 2.49 and $3.43 \mathrm{t} \mathrm{ha}^{-1}$ ) was observed under crop was sown on $2^{\text {nd }}$ December with application of four irrigation and $180 \mathrm{~N} \mathrm{~kg} \mathrm{ha}^{-1}: 90 \mathrm{P}_{2} \mathrm{O}_{5} \mathrm{~kg}$ $\mathrm{ha}^{-1}: 60 \mathrm{k} \mathrm{O} \mathrm{kg} \mathrm{ha}^{-1}$ over rest of the treatments. The crop sown on $2^{\text {nd }}$ December produced highest yield, mainly because it had the maximum plant height $(92.72 \mathrm{~cm})$, number of effective tillers $\left(297.83 \mathrm{~m}^{-2}\right)$, length of ear head $(7.90 \mathrm{~cm})$, no. of grains per earhead $(34.46)$ and 1000 grain weight $(41.61 \mathrm{~g})$, harvest index $(32.95 \%)$, net income (60234 ₹ ha-1) over other sowing dates. The production efficiency was also highest with $2^{\text {nd }}$ December ( $25.50 \mathrm{~kg} \mathrm{ha}^{-1} \mathrm{day}^{-1}$ ) sowing with four irrigation $\left(21.30 \mathrm{~kg} \mathrm{ha}^{-1}\right.$ day $\left.^{-1}\right)$ and $180 \mathrm{~N} \mathrm{~kg} \mathrm{ha}^{-1}: 90 \mathrm{P}_{2} \mathrm{O}_{5} \mathrm{~kg} \mathrm{ha}^{-1}: 60 \mathrm{k}_{2} \mathrm{O} \mathrm{kg}$ $\mathrm{ha}^{-1}\left(29.30 \mathrm{~kg} \mathrm{ha}^{-1} \mathrm{day}^{-1}\right)$. The lowest production efficiency was recorded on $12^{\text {th }}$ January $\left(19.40 \mathrm{~kg} \mathrm{ha}^{-1} \mathrm{day}^{-1}\right)$ in the three irrigation and lower dose of fertilizer.
\end{abstract}

Keywords: Wheat, sowing, irrigations, fertilizers, yield, net income

\section{Introduction}

Wheat (Triticum aestivum L.) is considered one of the most important cereal not only in India but also in the world. Its importance comes from using its grain as a main food source for human and its straw as feed for livestock. In India it occupies an area of about 30.5 mha with a production of 98.38 $\mathrm{mt}$ and with national productivity of $3216 \mathrm{~kg} \mathrm{ha}^{-1}$. In state of Madhya Pradesh it occupy in total 10.8 mha area with the production of $30.7 \mathrm{mt}$ and average productivity of $2478 \mathrm{~kg}$ ha $^{-1}$ (Anonymous, 2018). In India, around 13.5 mha of wheat is heat stressed (Joshi et al., 2007). The productivity of wheat is reduced considerably by combined stress of temperature and moisture than by either stress alone and has considerable effect on photosynthetic processes (Shah and Paulsen, 2003). As land and water resources are limited in India, increasing the productivity of wheat from the unit area is an important part in increasing the total production and minimizes the gap between consumption and production. Such target will be achieved by increasing the cultivated area, cultivating high yield varieties, and adoption of improved cultural practices. In spite of cultivation of high-yielding varieties, improved cultural practices and plant-protection measures, favorable weather is must for good harvest (Rao et al., 1999). ). Wheat yield is low in India on account of many biotic and abiotic factors. Among these, the time of sowing and planting density are of great significance which determine the proper stand establishment of the growing crop through balancing the plant to plant competition and ultimately affect the yield (Kabesh et al., 2009; Nakano and Morita, 2009). It has been observed that early sowing gives high yield than late sowing due to longer growing period (Suleiman et al., 2014) and vigorous growth associated with rapid and uniform seedling emergence and better combination of leaf size and tiller number. From an agronomic point of view, a key factor which is reflected in high wheat production is the well understanding of early crop establishment factors (Soomro et al., 2009) including time of planting, soil characteristics, seed viability and availability of plant machinery (Sulieman, 2010). It is important to define the optimal sowing date and seeding rate of winter wheat, due to the climate-change of habitats, not only from agro-technical factors (sowing date), but also from economic point of view. Wheat grows mainly during dry seasons, where irrigation 
is necessary because precipitation in the growing season is far less than the crop water requirement. However, water resources are usually limited. Hence, irrigation scheduling is used to allocate irrigation water rationally in crop growing stages in order to maximize crop yield, water productivity and profit under the limited conditions (Thorat et al., 2015). Wheat is sensitive to moisture stress, it needs frequent irrigation for good growth and yield (Mishra et al., 1995; Alderfasi and Nielsen., 2001). But yield increase and water use efficiency decrease above 4 irrigations (Chen et al., 2014). The crop parameters and yield of wheat were significantly higher under high frequency irrigation and grain yield reduced drastically with increase in maximum allowable depletion (MAD) of available soil water from 40-75\% (Mugabe and Nyakatawa, 2000; Panda et al., 2003; Gontia and Tiwari, 2008). Fertilizers constitute an integral part of improved cropproduction technology. Proper amount of fertilizer application is considered a key to the bumper crop production (Prasad et al., 2016). In addition, there is a synergy between fertilizer and water for their effects on wheat productivity more so in arid and semi-arid regions that generally experience nitrogen deficiency. However, both water and nitrogen are subjected to losses by many pathways if not managed properly. Consequently, there is a considerable interest in technologies that enhance nitrogen use efficiency and productive use of applied irrigation water leading to increased productivity. Keeping view in mind, the experiment had been conducted to find out optimum dose of fertilizer and irrigation level under different environment for yield maximization.

\section{Materials and Methods}

The experiment was carried out at Research Farm of Jawaharlal Nehru Krishi Vishwa Vidyalaya, Jabalpur, Madhya Pradesh, India located at latitude $23.20722^{\circ}$ and longitude $79.9539^{\circ}$ during winter season 2015-16. The soil of the experimental site was sandy clay loam with $\mathrm{pH} 7.5, \mathrm{EC} 0.48 \mathrm{dS} \mathrm{m}^{-1}$ and $0.68 \%$ OC. The total rainfall was $135 \mathrm{~mm}$ received during crop season. The total 24 treatments combinations were evaluated in a split-split plot design with three replications, three sowing dates $\left(D_{1}-2^{\text {nd }}\right.$ December, $D_{2}-22^{\text {th }}$ December and $D_{3}-12^{\text {th }}$ January) as main-plot treatment, two Irrigation schedules$\left(\mathrm{I}_{1}\right.$-Three irrigations at $\mathrm{CRI}+$ flowering stage+milk stage and $\mathrm{I}_{2}$-Four irrigations at $\mathrm{CRI}+$ late jointing stage+flowering stage) were as sub-plot treatment and four Fertilizer levels $\left(F_{1}-N_{0}\right.$ Fertilizer, $\mathrm{F}_{2}-60 \mathrm{~N} \mathrm{~kg} \mathrm{ha}^{-1}: 30 \mathrm{P}_{2} \mathrm{O}_{5} \mathrm{~kg} \mathrm{ha}^{-1}: 20 \mathrm{k}_{2} \mathrm{O} \mathrm{kg} \mathrm{ha}^{-1}, \mathrm{~F}_{3}-120$ $\mathrm{N} \mathrm{kg} \mathrm{ha}{ }^{-1}: 60 \mathrm{P}_{2} \mathrm{O}_{5} \mathrm{~kg} \mathrm{ha}^{-1}: 40 \mathrm{k}_{2} \mathrm{O} \mathrm{kg} \mathrm{ha}^{-1}$ and $\mathrm{F}_{4}-180 \mathrm{~N} \mathrm{~kg} \mathrm{ha}^{-1}: 90$ $\mathrm{P}_{2} \mathrm{O}_{5} \mathrm{~kg} \mathrm{ha}^{-1}: 60 \mathrm{k}_{2} \mathrm{O} \mathrm{kg} \mathrm{ha}{ }^{-1}$ ) were as sub-sub plot treatment. Fertilizers were applied in the plots in the form of urea (source of nitrogen), DAP (source of phosphorus) and MOP (source of potassium) respectively. Half of the recommended dose of nitrogen and all of the phosphorus and potash were applied at the time of sowing, while the remaining nitrogen was applied as top dressing through broadcasting. Immediately after crop establishment, five plants were randomly selected from each plot for recording periodical observations on yield attributing parameter like number of tillers, number of effective tillers, earhead length, number of grains per earhead, 1000-grain weight, grain yield and straw yield. The data collected were statistically analysis as per method of "Analysis of variance Technique" appropriate for split-split plot design for interpretation of results given by Steel and Torrie, 1960.

\section{Results and Discussion}

\subsection{Effect of date of sowing}

In this present investigation yield, yield attributes and economics of wheat differ significantly under crop down at different dates. The plant height $(92.72 \mathrm{~cm})$, number of effective tillers $\mathrm{m}^{-2}$ (297.83), earhead length $(7.90 \mathrm{~cm})$, number of grains per earhead (34.46) and 1000 grain weight (41.61 g) were recorded higher when crop sown on $2^{\text {nd }}$ December over rest of the dates. Grain yield $\left(2.98 \mathrm{t} \mathrm{ha}^{-1}\right)$, straw yield ( 6.55 tha$\left.{ }^{1}\right)$, harvest index (32.95\%), production efficiency (25.50 kgha-1 day $^{-1}$ ) and net income ( $₹ 60234 \mathrm{ha}^{-1}$ ) were also maximum than other sowing dates (Table 1). Agrawal et al. (2001), Throat et al. (2015), Jat et al. (2013), Tomar et al. (2014); Tahir et al. (2009) also found similar results.

\subsection{Effect of irrigation schedules}

Irrigation at every critical and sensitive stages are directly affect the crop yield and productivity. Four irrigations at crown root initiation, late tillering, flowering and milk stages are produced maximum yield, attributes and income. The plant height $(86.67 \mathrm{~cm})$, number of effective tillers $\mathrm{m}^{-2}(277.19)$, earhead length $(7.78 \mathrm{~cm})$, number of grains per earhead (33.61) and 1000 grain weight ( $41.39 \mathrm{~g}$ ) were recorded higher when four irrigation were given to crop over there irrigations. Grain yield $\left(2.49\right.$ tha $\left.^{-1}\right)$, straw yield $\left(5.44 \mathrm{t} \mathrm{ha}^{-1}\right)$, harvest index (33.13\%), production efficiency (23.32 $\mathrm{kg} \mathrm{ha}^{-1} \mathrm{day}^{-1}$ ) and net income ( $₹ 73642 \mathrm{ha}^{-1}$ ) were also maximum than three irrigations (Table 1) (Mukherjee, 2012; Thorat et al., 2015). The yield increases for both grain and straw 3.3 and $1.1 \%$ respectively however, profit increase was in the tune of Rs. 16871 due to the different in difference in costs involved.

\subsection{Effect of fertilizer dose}

This experiment was consisted of four fertilizer levels (no fertilizer, $60 \mathrm{~N} \mathrm{~kg} \mathrm{ha}^{-1}: 30 \mathrm{P}_{2} \mathrm{O}_{5} \mathrm{~kg} \mathrm{ha}^{-1}: 20 \mathrm{k}_{2} \mathrm{O} \mathrm{kg} \mathrm{ha}^{-1}, 120 \mathrm{~N} \mathrm{~kg}$ $h^{-1}: 60 \mathrm{P}_{2} \mathrm{O}_{5} \mathrm{~kg} \mathrm{ha}^{-1}: 40 \mathrm{k}_{2} \mathrm{O} \mathrm{kg} \mathrm{ha}^{-1}$ and $180 \mathrm{~N} \mathrm{~kg} \mathrm{ha}^{-1}: 90 \mathrm{P}_{2} \mathrm{O}_{5} \mathrm{~kg}$ $\left.\mathrm{ha}^{-1}: 60 \mathrm{k}_{2} \mathrm{O} \mathrm{kg} \mathrm{ha-1}\right)$. Superior plant height $(94.61 \mathrm{~cm})$, no. of effective tillers $\mathrm{m}^{-2}$ (328.94), earhead length $(8.48 \mathrm{~cm})$, number of grains per earhead (39.17) and 1000 grain weight (42.16 g) were recorded when $180 \mathrm{~N} \mathrm{~kg} \mathrm{ha}^{-1}: 90 \mathrm{P}_{2} \mathrm{O}_{5} \mathrm{~kg} \mathrm{ha}^{-1}: 60 \mathrm{k}_{2} \mathrm{O}$ $\mathrm{kg} \mathrm{ha}^{-1}$ given to crop over rest of the treatments. Grain yield (3.38 tha $\left.{ }^{-1}\right)$, straw yield $\left(7.79\right.$ tha $\left.^{-1}\right)$, harvest index $(30.07 \%)$, production efficiency ( $31.96 \mathrm{~kg} \mathrm{ha}^{-1} \mathrm{day}^{-1}$ ) and net income ( $₹$ $56728 \mathrm{ha}^{-1}$ ) were also higher over rest of the treatments. Ram et al., 2012, Prasad et al., 2016 also found related findings. 


\begin{tabular}{|c|c|c|c|c|c|c|c|c|c|c|}
\hline Treatments & $\begin{array}{l}\text { Plant } \\
\text { height } \\
(\mathrm{cm})\end{array}$ & $\begin{array}{l}\text { No. of } \\
\text { effective } \\
\text { tillers } \mathrm{m}^{-2}\end{array}$ & $\begin{array}{l}\text { Length } \\
\text { of } \\
\text { earhead } \\
(\mathrm{cm})\end{array}$ & $\begin{array}{l}\text { No. of } \\
\text { grains } \\
\text { ear- } \\
\text { head }^{-1}\end{array}$ & $\begin{array}{l}1000 \\
\text { grain } \\
\text { weight } \\
(\mathrm{g})\end{array}$ & $\begin{array}{l}\text { Grain } \\
\text { Yield } \\
\left(\mathrm{t} \mathrm{ha}^{-1}\right)\end{array}$ & $\begin{array}{l}\text { Straw } \\
\text { Yield } \\
\left(\mathrm{t} \mathrm{ha}^{-1}\right)\end{array}$ & $\begin{array}{c}\text { Harvest } \\
\text { index } \\
(\%)\end{array}$ & $\begin{array}{c}\text { Produc- } \\
\text { tion effi- } \\
\text { ciency (kg } \\
\text { ha }^{-1} \text { day }^{-1} \text { ) }\end{array}$ & $\begin{array}{l}\text { Net in- } \\
\text { come } \\
\left(₹ h^{-1}\right)\end{array}$ \\
\hline \multicolumn{11}{|l|}{ Date of sowing } \\
\hline$D_{1}-2^{\text {nd }}$ Dec. & 92.72 & 297.83 & 7.90 & 34.46 & 41.61 & 3.22 & 6.55 & 32.95 & 25.50 & 60234 \\
\hline$D_{2}-22^{\text {nd }}$ Dec. & 86.21 & 292.25 & 7.85 & 32.83 & 39.33 & 2.56 & 5.61 & 31.33 & 23.93 & 51352 \\
\hline $\mathrm{D}_{3}-12^{\text {th }}$ Jan. & 78.40 & 284.13 & 7.72 & 32.00 & 39.81 & 1.84 & 4.07 & 31.13 & 19.40 & 37855 \\
\hline SEm \pm & 2.14 & 2.43 & 0.08 & 0.72 & 0.26 & 0.20 & 0.23 & 0.22 & 1.56 & \\
\hline $\mathrm{CD}(p=0.05)$ & 6.26 & 6.6202 & 0.2431 & 2.2571 & 0.7737 & 0.599 & 0.680 & 0.67 & 4.679 & \\
\hline \multicolumn{11}{|l|}{ Irrigation schedules } \\
\hline $\mathrm{I}_{1}-\mathrm{CRI}+\mathrm{FL}+\mathrm{ML}$ & 80.7 & 277.19 & 7.78 & 32.58 & 39.11 & 2.40 & 5.38 & 30.85 & 22.56 & 56771 \\
\hline $\mathrm{I}_{2}-\mathrm{CRI}+\mathrm{LJ}+\mathrm{FL}+\mathrm{ML}$ & 86.67 & 305.61 & 7.87 & 33.61 & 41.39 & 2.48 & 5.44 & 31.31 & 23.32 & 73642 \\
\hline SEm \pm & 0.8 & 2.49 & 0.041 & 0.32 & 0.21 & 0.117 & 0.137 & 0.127 & 1.11 & \\
\hline $\mathrm{CD}(p=0.05)$ & 2.41 & 7.4862 & 0.1233 & 0.9588 & 0.6211 & 0.351 & 0.413 & 0.382 & 3.318 & \\
\hline \multicolumn{11}{|l|}{ Fertility levels } \\
\hline $\mathrm{F}_{1}$ : Nodose (Control) & 69.55 & 262.11 & 7.45 & 28.44 & 38.47 & 1.29 & 1.87 & 40.82 & 12.60 & 30034 \\
\hline $\begin{array}{l}\mathrm{F}_{2}: 60 \mathrm{~N} \mathrm{~kg} \mathrm{ha}^{-1}: 30 \mathrm{P}_{2} \mathrm{O}_{5} \\
\mathrm{~kg} \mathrm{ha}^{-1}: 20 \mathrm{k}_{2} \mathrm{O} \mathrm{kg} \mathrm{ha-1}\end{array}$ & 79.64 & 279.28 & 7.55 & 30.17 & 39.99 & 2.36 & 5.25 & 31.01 & 21.89 & 41113 \\
\hline $\begin{array}{l}\mathrm{F}_{3}: 120 \mathrm{~N} \mathrm{~kg} \mathrm{ha}^{-1}: 60 \\
\mathrm{P}_{2} \mathrm{O}_{5} \mathrm{~kg} \mathrm{ha}^{-1}: 40 \mathrm{k}_{2} \mathrm{O} \mathrm{kg}^{-1}\end{array}$ & 87.43 & 295.28 & 7.86 & 35.22 & 40.56 & 2.76 & 6.64 & 29.36 & 25.74 & 49346 \\
\hline $\begin{array}{l}\mathrm{F}_{4}: 180 \mathrm{Nkgha}^{-1}: 90 \mathrm{P}_{2} \mathrm{O}_{5} \\
\mathrm{~kg} \mathrm{ha-1}: 60 \mathrm{k}_{2} \mathrm{O} \mathrm{kg} \mathrm{ha-1}\end{array}$ & 94.61 & 328.94 & 8.48 & 39.17 & 42.16 & 3.35 & 7.79 & 30.07 & 31.96 & 56728 \\
\hline SEm \pm & 3.03 & 3.51 & 0.047 & 0.383 & 0.204 & 0.093 & 0.151 & 0.12 & 0.758 & \\
\hline $\mathrm{CD}(p=0.05)$ & 9.09 & 10.5202 & 0.1397 & 1.1490 & 0.6114 & 0.278 & 0.454 & 0.37 & 2.273 & \\
\hline
\end{tabular}

CRI: Crown root initiation; LJ: Late jointing stage; FL: Flowering stage; ML: Milk stage

\section{Conclusion}

Higher plant height, number of effective tillers $/ \mathrm{m}^{2}$, length of earhead, number of grains per earhead, 1000 grain weight, harvest index, production efficiency, net income, grain and straw yield was recorded in wheat sown on $2^{\text {nd }}$ December with four irrigations and $180 \mathrm{~N} \mathrm{~kg} \mathrm{ha}^{-1}: 90 \mathrm{P}_{2} \mathrm{O}_{5} \mathrm{~kg} \mathrm{ha}^{-1}: 60 \mathrm{k}_{2} \mathrm{O} \mathrm{kg} \mathrm{ha}^{-1}$.

\section{References}

Anonymous, 2018. Agricultural Statistics at a Glance.

Agrawal, K.K., Upadhyay, A.P., Upendra, S., Gupta, V.K., 2001. Phenological behaviour and thermal requirements of wheat genotypes under different dates of sowing. Annals of Plant and Soil Research 3(1), 12-16.

Chen, S., Sun, H., Shao, L., Zhang, X., 2014. Performance of winter wheat under different irrigation regimes associated with weather conditions in the North China Plain, Australian Journal of Crop Science 8(4), 550-557.

Gontia, N.K., Tiwari, K.N., 2008. Development of crop water stress index of wheat crop for scheduling irrigation using infrared thermometry. Agricultural Water Management 95(10), 1144-1152.

Jat, L.K., Singh, S.K., Latare, A.M., Singh, R.S., Patel, C.B., 2013. Effects of dates of showing and fertilizer on growth and yield of wheat (Triticum aestivum L.) in an inseptisol of Varanasi. Indian Journal of Agronomy 52 (4), 168-171.

Joshi, A.K., Mishra, B., Chatrath, R., Ortiz, F.G., Singh, R.P., 2007. Wheat improvement in India: present status, emerging challenges and future prospects. Euphytica $157(3), 431-446$.

Kabesh, M.O., El-kramany, M.F., Sary, G.A., El- Naggar, H.M., Gehan, S.H.B., 2009. Effects of sowing methods and some bio-organic fertilization treatments on yield and yield components of wheat. Research Journal of Agricultural and Biological Science 5, 97-102.

Mugabe, F.T., Nyakatawa, E.Z., 2000. Effect of deficit irrigation on wheat and opportunities of growing wheat on residual soil moisture in southeast Zimbabwe, Agricultural Water Management 46(2), 111-119.

Mukherjee, D., 2012. Effect of different sowing dates on 
growth and yield of wheat (Triticum aestivum) cultivars under mid-hill situation of West Bengal, Indian Journal of Agronomy 57(2), 152-56.

Nakano, H., Morita S., 2009. Effects of seeding rate and nitrogen application rate on grain yield and protein content of the bread wheat cultivar 'Minaminokaori' in Southwestern Japan. Plant Production Science 12, 109-115.

Panda, R.K., Behera, S.K., Kashyap, P.S., 2003. Effective management of irrigation water for wheat under stressed conditions, Agricultural Water Management 63(1), 37-56.

Prasad, S., Agrawal, K.K., 2016. Production potential of heat tolerant wheat (Triticum aestivum L.) cultivars as affected by different sowing time and nutrient management under Jabalpur condition of Madhya Pradesh, Advances in Life Sciences 5(16), 5827-5829.

Ram, A., Pannu, R.K., Prasad, D., 2012. Effect of management practices on growth, yield and quality of late sown wheat (Triticum aestivum). Indian Journal of Agronomy 57(1), 92-95.

Rao, G.G., Kesava, S.N., Rao, A.V.R., Ramakrishna, Y.S., Victor, W.S., 1999. Resources characterization of Drylands: Climate (In) Fifty Years of Dryland Agricultural Research in India Singh et al. (Eds.), CRIDA, Hyderabad.

Shah, N.H., Paulsen, G.M., 2003. Interaction of drought and high temperature on photosynthesis and grain filling of wheat, Plant and Soil 257(1), 219-26.

Sharma, A., Rawat, U.S., Yadav, B.K., 2012. Influence of phosphorus levels and phosphorus solubilizing fungi on yield and nutrient uptake by wheat under sub-humid region of Rajasthan. India ISRN Agronomy 2012, 1-17.

Sheoran, H.S., Duhan, B.S., Grewal, K.S., Sheoran, S., 2015. Grain yield and NPK uptake of wheat (Triticum aestivum L.) as influenced by nitrogen, vermicompost and herbicide (Clodinafop propargyl). African Journal of Agricultural Research 10(42), 3952-3961.
Soomro, U.A., Rahman, M.U., Odhano, E.A., Gul, S., Tareen, A., 2009. Effects of sowing method and seed rate on growth and yield of wheat (Triticum aestivum. L). World Journal of Agricultural Science 5, 159-162.

Steel, R.G.D., Torrie, J.H., 1960. Principles and Procedures of Statistics. Mc Graw-Hill Kogakusha Ltd., Tokyo.

Sulieman, S.A., 2010. The Influence of Triticum asetivum seeding rates and sowing patterns on the vegetative characteristics in Shambat soil under irrigation. Research Journal of Agriculture and Biological Science 6(2), 93-102.

Thorat, T.N., Agrawal, K.K., Bhan, Manish, 2016. Phenological development and yield of wheat cultivars under different crop growing environment and irrigation schedules. Green farming 7, 1-6.

Tripathi, S.C., Chander, S., Meena, R.P., 2013. Effect of early sowing, $\mathrm{N}$ levels and seed rates on yield and yield attributes of different wheat (Triticum aestivum L.) varieties. Indian Journal of Agronomy 58(1), 63-66.

Tomar, S.P.S., Tomar, S.S., Srivastava, S.C., 2014. Yield and yield component response of wheat (Triticum aestivum L.) genotypes to different sowing dates in Gird region of Madhya Pradesh. International Journal of Farm Sciences $4(2), 1-6$.

Tahir, M., Ali, A., Ather, N.M., Hussain, A., Khalid, F., 2009. Effect of different sowing dates on growth and yield of wheat (Triticum aestivum L.) varieties in district Jhang Pakistan, Pakistan Journal of Life Sciences 7(1), 66-69.

Tyagi, V., Singh, R.K., Nagargade, M., 2015. Effect of hydrogel, NPK and irrigation levels on yield, nutrient uptake and water use efficiency of wheat (Triticum aestivum L.). Research on Crops 16(4), 653-656.

Youssef, S.M., Faizy, S.E.D., Mashali, S.A., Ramady, H.R.E.I., Ragab, S.H., 2013 .Effect of different levels of NPK on wheat crop in North Delta. Journal of Agriculture Research Tanta University 12(4), 1205-1217. 